\title{
Study of $\gamma^{\prime}$ phase at early aging stages in $\mathrm{Ni}-15 \mathrm{at} \% \mathrm{Al}$ alloy by election microscope
}

\section{$\mathrm{N}$ i -15 a t \% 合金の時効初期における $\gamma^{\prime}$ 相の電子顕微鏡による観察}

Chie Murai, Tadae Morishita and Tsunenori Suzuki

Department of Physics, Faculty of Science, Tokai University

Department of Production Engineering, School of Engineering,

Tokai University, 1117 Kitakaname, Hiratsuka, Kanagawa, 259-12 Japan

( Accepted for publication 17 November 1994 )

\section{1.緒言}

Ni-15at\%A1合金の過飽和固溶体を時効すると、2相に 分離し、 $\gamma^{\prime}$ 相が析出される。従来の研究の多くは長 時間時效した $\gamma^{\prime}$ 相の生長過程でり、時效初期の $\gamma^{\prime}$ 粒子については、西まり研究されていない。それ は固体急泠法で作成されたため、時効前の試料には大 きな澧度氻らざが存在し、時効前の試料の条件が一定 にならなかった為である1。をこて液体急泠法を用い て溶篗浀度沛らぎの少ない時効前の試料を作成した1。 本研究虫時效初期について $\gamma^{\prime}$ 析出粒子の成長過程を 透過型電子影微鏡で観測し、研究を行った。

\section{2. 実験方法}

$\mathrm{Ni}-15 \mathrm{at} \% \mathrm{Al}$ 合金の母合金より、ピストン・アンビル

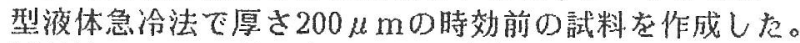
試料は873KでArガス中において時效し、 $\gamma^{\prime}$ 相を析出 させた。電子顕微鏡に用いる試料は厚さ約 $50 \mu \mathrm{m}$ まで エメリー紙を用いて薄くした。をの後、試料に陽梂を 接続し、陰極にスデンレスを用いて、最初は酷酸15対 過塩素酸10エッチング液て、次に硫酸 $55 \%$ 水溶液で雷 解研磨した。電子顕微鏡の加速電王虫、100kVと 120 kVで、(100)暗視像で観测した。

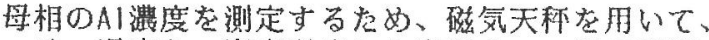
キュリ一温度を、䇪素温度から室温までの温度螌㜀で 測定した。A1浀度C(AI)とキュリ一温度TCの関係は、 W.0.Gentryらにより次式で表される2。

$C(A 1)=20.0 \times(1-\mathrm{Tc} / 631)$

\section{3.結果㧍よび考察}

Figure 1(A) 〜 C C \&Ni-15at尔A1在873Kで時効し、 $\gamma$ '相を析出させを試料 像で岗当。Fig.1(A)执よど1(B)に示した873Kの時效初 期の試料には、球状のL12規則相が出現してい当。球状 $\gamma^{\prime}$ 粒子の暗視野像は索委り明確になっていないが、 時効時間が增加しても、 $\gamma^{\prime}$ 相の大ささ偣加してい ない。生た、暗視野像の不明確さは、L12規則相の規則 度が低いことを示している。この段階ではと粒子が まだ25a活Aに達していないと思われる。

Figure2にキュリ一温度測定で得られた母相の溶篗惯

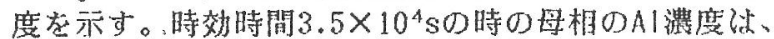
太きく減少している。こ机析出した $\gamma^{\prime}$ 相が安定な

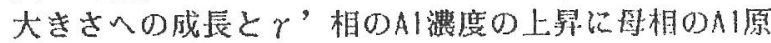
子を取り迅んているむので节ると考免られる(Fig.3)。

Figure1(C)に示求ように、長時闑時效で蛅、立方体

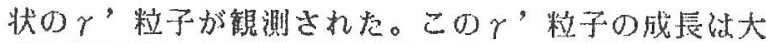
きな粒子が小さい粒子空消減させつつ、粗大化する過 程である。この過程は立方体の辺の3乗が時閒に比例 して增加する才ストりルド成長である。

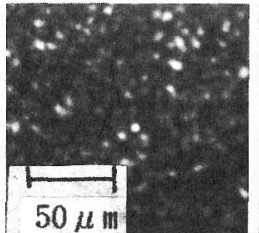

(A) $5 \times 10^{3} \mathrm{~s}$

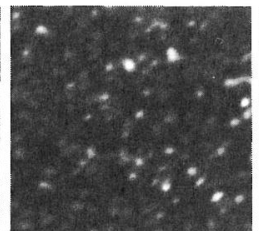

(B) $1 \times 10^{4} \mathrm{~s}$

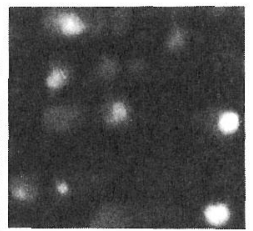

(c) $5.5 \times 10^{5} \mathrm{~s}$
Fig. 1873 Kで時効した試料の透過型電子 顕微鏡写真（暗視野像）

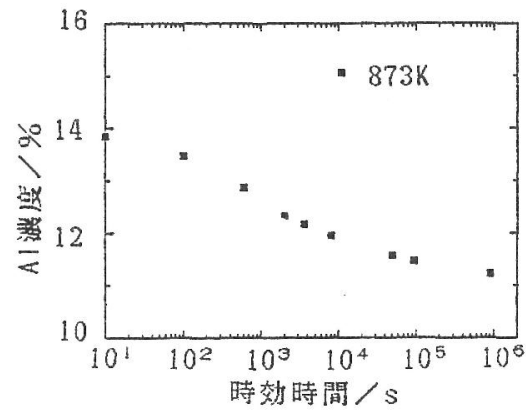

Fig. 2 キュリー温度の時効時間変化

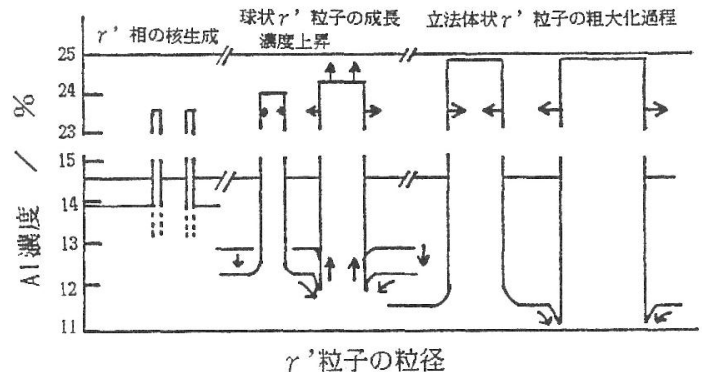

Fig. $3 \gamma^{\prime}$ 粒子の成長七母相の溶質濃度变化の模式図 参考文献

1 A.Tachikake,T.Suzuki, Y.Nishi and E.Ya,ima, 日本金属学会誌 49(1985)818

${ }^{2}$ W.0.Gentry and M.E.Fine,Acta Met.20(1972)181 194 SAS Intelligent Symposium 